УДК 343.851.5:340.114.5

\title{
О.В. Лещценко
}

\section{К ВОПРОСУ О ПОНИМАНИИ РЕФЛЕКСИИ ПРАВОСОЗНАНИЯ НЕСОВЕРШЕННОЛЕТНИХ ОСУЖДЕННЫХ}

Аннотация: в современных условиях реформирования сочиально-правовой сферы российского государства, развития правовой грамотности и правосознания граждан весьма важным является понимание рефлексии правосознания как своеобразного и целостного феномена. Автором статьи проведен анализ действующих правовых норм государства, которые способствуют формированию правосознания несовершеннолетних осужденных; представлено современное понимание явления рефлексии правосознания несовершеннолетнего осужденного как состояния, отражающего собственное сознание индивида о понимании норм права и законов.

Ключевые слова: правосознание, несовершеннолетние, рефлексия правосознания, несовершеннолетние осужденные, права ребенка, правовое просвещение, правовая культура, общество.

\section{O.V. Leshhenko \\ REVISITING THE UNDERSTANDING OF LEGAL CONSCIOUSNESS REVIEW OF CONVICTED MINORS}

Abstract: under the modern reform of social and legal sphere in the Russian state and expansion of citizens' legal consciousness it is important is to understand legal consciousness review as a unique and holistic phenomenon. The author analyses current rules of the state which promote legal consciousness of convicted minors. The research presents the modern understanding of such phenomenon as legal consciousness review of convicted minors as a condition reflecting individual's consciousness in understanding laws and statutes.

Keywords: legal consciousness, minors, legal consciousness review, convicted minors, child's rights, legal behavior, legal culture, society. 
Современные условия развития российского государства диктуют новые принципы построения законопослушного гражданского общества с развитым правовым мышлением, приоритетом прав и свобод человека, высоким уровнем правовой культуры и правосознания. Такие принципы построения социальноправового государства смогут должным образом укрепить правопорядок, обеспечить верховенство закона, гарантировать надежную защиту граждан в любых сферах жизни общества.

Необходимо отметить важность закрепления таких принципов на стадии реформирования пенитенциарной системы государства, развития взаимосвязей государственных органов и институтов гражданского общества. Действующая Концепция развития уголовно-исполнительной системы Российской Федерации до 2020 года [1] направлена на повышение эффективности работы исправительных учреждений до уровня европейских стандартов обращения с осужденными, гарантий соблюдения прав и законных интересов осужденных, качественной социальной и психологической работы с осужденными в местах лишения свободы. Правительством РФ в 2014 году была утверждена государственная программа «Юстиция» [4], главной целью которой является развитие в обществе правовой модели поведения граждан, преодоление правового нигилизма, поддержание устойчивого уважения к закону и повышение доверия к правосудию.

Сегодня проводится государственная политика в сфере развития правовой грамотности и правосознания граждан, главные цели которой заключаются в формировании в обществе устойчивого уважения к закону и преодолению правового нигилизма; повышении уровня правовой культуры граждан, включая уровень осведомленности и юридической грамотности; создании системы стимулов к законопослушанию как основной модели социального поведения; внедрении в общественное сознание идеи добросовестного исполнения обязанностей и соблюдения правовых норм [6].

Приведенные данные позволяют судить о значимости происходящих в жизни нашего государства и общества процессов совершенствования социальноправовой сферы и дают возможность установить взаимосвязь между правами 
граждан, закрепленными на законодательном уровне, с особенностями формирования правосознания различных субъектов правоотношений.

Несовершеннолетние выступают самостоятельным субъектом таких правоотношений, так как именно их законные права и свободы регламентируются специальными правовыми актами, как национального законодательства, так и нормами международного права. В силу возрастных особенностей им присущи неустоявшаяся психика и несформированная система ценностей и представлений о законах, нормах права. Поэтому законодательные основы развития их правосознания должны находить свое начало именно в правовых нормах государства как гаранта соблюдения прав и свобод человека.

В сегодняшних условиях правовой действительности особенно актуально развитие института защиты прав, интересов ребенка и правовое просвещение детей. Особая роль в решении данных вопросов отведена независимому государственному правовому институту - федеральным и региональным омбудсменам по правам ребенка. Так же в рамках реализуемой в нашей стране национальной стратегии действий в интересах детей на 2012-2017 годы [2] дети имеют право на особую заботу и помощь со стороны государства, и государственная политика в данной области осуществляется на принципах и нормах международного права.

Государство признает детство важным этапом жизни человека и исходит из принципов приоритетности подготовки детей к полноценной жизни в обществе, развития у них общественно значимой и творческой активности, воспитания в них высоких нравственных качеств, патриотизма и гражданственности [3].

В настоящее время несовершеннолетние осужденные как отдельная социально-демографическая группа наиболее уязвимы во всех сферах реализации прав ребенка. Дети, отбывающие наказания в условиях изоляции от общества находятся в трудной жизненной ситуации и им нужна поддержка со стороны сотрудников воспитательных колоний, родителей, родственников, педагогов, психологов и, конечно же, со стороны государства и общества в целом. Данная группа требует наиболее пристального внимания со стороны уполномоченных 
по правам ребенка, правозащитных организаций и различных институтов гражданского общества.

Правовое сознание является ключевым компонентом теории и права любого государства. С точки зрения теории правовое сознание есть форма общественного сознания, составляющая совокупность правовых взглядов и чувств, обладающих нормативным характером и состоящих из знаний и оценки правовых явлений с учетом справедливости и новых правовых требований, которые выражаются через различные потребности и интересы общественного развития $[9$, c. 70,96$]$.

Особую форму отражения правового сознания индивида представляет рефлексия данного феномена. Так рефлексия правового сознания несовершеннолетних заключается в отражении своего собственного сознания и мыслей о происходящих правовых явлениях и процессах и основывается на представлениях и знаниях о правах индивидуума. К основным законодательным нормам о правах ребенка можно отнести следующие нормативно-правовые акты РФ и международные документы:

- Конвенция ООН о правах ребенка и факультативные протоколы к ней;

- Конституция РФ;

- Семейный кодекс РФ;

- Федеральный закон от 24.07.1998 №124-Ф3 «Об основных гарантиях прав ребенка в Российской Федерации» и др.

Незнание собственных прав осужденными и неумение их отстоять тормозит процесс формирования правосознания и процесс их правовой социализации [7, с. 430]. Исследование вопросов формирования правосознания несовершеннолетних осужденных должно проводиться с учетом специфики нахождения в исправительном учреждении и при понимании того, что их правовое сознание формируется в процессе общения с таким же сверстниками-правонарушителями, как и они сами. Поэтому самопознание, понимание и сопоставление внутреннего мира и знаний о нормах права, правопорядке, законности таких лиц должно происходить одновременно с изучением знаний о правах ребенка. Так как рефлексия 
правосознания несовершеннолетних осужденных ограничивается условиями пребывания в исправительном учреждении, то права таких детей дополнительно регламентируются Уголовно-исполнительным кодексом РФ [8] и правилами внутреннего распорядка исправительных учреждений [5].

Таким образом, рефлексия правового сознания несовершеннолетнего осужденного - это состояние, отражающее собственное сознание индивида о понимании норм права, законов, правопорядке, правонарушениях и принцип мышления, при котором несовершеннолетний в условиях изоляции от общества способен осмыслить и осознать посредством уже имеющихся или полученных знаний сущность законодательных начал происходящей правовой действительности. Данное состояние и принцип мышления должны происходить у несовершеннолетнего осужденного с учетом полученных в период отбывания наказания понятий и представлений о правах ребенка. Только при таком подходе государству удастся успешно реализовать действующие программы по развитию правовой грамотности, правосознанию и правовому просвещению граждан, укрепить институт защиты прав и интересов ребенка, подготовить детей, в том числе несовершеннолетних осужденных, к полноценной жизни в обществе и закрепить в их сознании высокие нравственные и правовые начала.

\section{Сиисок литературы}

1. О Концепции развития уголовно-исполнительной системы Российской Федерации до 2020 года: распоряжение Правительства РФ от 14.10.2010 №1772-р в ред. от 23.09.2015 // Собрание законодательства РФ, 25.10.2010. №43. - C. 5544.

2. О Национальной стратегии действий в интересах детей на 2012-2017 годы: Указ Президента РФ от 01.06.2012 №761 // Собрание законодательства РФ, 04.06.2012. - №23. - С. 2994.

3. Об основных гарантиях прав ребенка в Российской Федерации: Федеральный закон от 24.07.1998 №124-Ф3 в ред. от 28.11.2015 // Собрание законодательства РФ, 03.08.1998. - №31. - С. 3802. 
4. Об утверждении государственной программы Российской Федерации «Юстиция»: Постановление Правительства РФ от 15.04.2014 №312 // Собрание законодательства РФ, 05.05.2014. - №18. - Ч. 2. - С. 2158.

5. Об утверждении Правил внутреннего распорядка исправительных учреждений: Приказ Минюста России от 03.11.2005 №205 в ред. от 12.02.2009, с изм. от 07.02.2012 // Бюллетень нормативных актов федеральных органов исполнительной власти. - №47 (21.11.2005).

6. Основы государственной политики Российской Федерации в сфере развития правовой грамотности и правосознания граждан, утвержденные Президентом РФ 28.04.2011 № Пр-1168 // Российская газета. - №151 (14.07.2011).

7. Сапогов В.M. Воспитанники учреждений закрытого типа как субъекты социально-правовой дефицитарности // Проблемы борьбы с преступностью и подготовки кадров для правоохранительных органов: Тезисы докладов Международной научно-практической конференции (Минск, 7 апреля 2016 г.). - Минск: Академия Министерства внутренних дел Республики Беларусь. - С. 430-431.

8. Уголовно-исполнительный кодекс Российской Федерации от 08.01.1997 №1-Ф3 в ред. от 28.11.2015 // Собрание законодательства РФ, 13.01.1997. - №2. C. 198 .

9. Фарбер И.Е. Правосознание как форма общественного сознания. - М.: Юридическая литература, 1963. - 205 с.

Лещенко Ольга Вадимовна - преподаватель кафедры уголовно-правовых дисциплин Псковского филиала ФКОУ ВО «Академия права и управления ФСИН России», Россия, Псков.

Leshhenko Olga Vadimovna - lecturer of Criminal-law Disciplines Department of Pskov branch of "The Academy of the Federal Penal Service of Russia”, Russia, Pskov. 